\section{Tatiana Zachar Podolinská, Marian Devotion among the Roma in Slovakia: A Post-Modern Religious Response to Marginality,}

\section{Cham: Palgrave Macmilian 2021, $166 \mathrm{~s}$.}

\section{ISBN 978-3-030-56363-9.}

Kniha slovenské etnoložky Tatiany Zachar Podolinské je čerstvým a svěžím počinem v oblasti studia náboženství v současné Evropě. Nabízí pestrý pohled do světa romského tradičního křestanství, ale nevyhýbá se ani poučeným interpretacím a predikcím. Již titul publikace prozrazuje mnohé o tom, jakým směrem se text ubírá: není jen popisem různých podob uctívání Panny Marie mezi slovenskými Romy, ale zasazuje tyto aktivity také do postmoderního kontextu a především do souvislosti s marginalizací a diskriminací. Ukazuje, jak se Romové na Slovensku z hlediska náboženství ocitají ve slepé uličce: katolictvím jsou veskrze přehlíženi a ani vysoce oblíbená figura Panny Marie jim nenabízí smysluplnou emancipaci; misijně aktivní letniční hnutí zase nabízejí novou (nicméně stále marginální) identitu, a navíc Romy o pomocnou ruku Panny Marie připravují.

Jde tedy o vysoce aktuální a zároveň smysluplně vymezené téma, které se autorce daří uchopovat srozumitelným a jednoznačným jazykem. Hned na začátku bych chtěla podotknout, že i přes několik nedostatků popsaných níže je kniha velice kvalitní, podložená důkladnou prací.

Publikace má logickou strukturu a udržuje čtenáře stále v souvislostech. Autorka se nepochybně v terénu pohybuje dlouho, má obdivuhodné znalosti a dokáže je atraktivně zprostř̌edkovat. Klíčovou otázkou její publikace je role dvou odlišných podob křestanství, katolictví a letničního hnutí, v romské emancipaci. Ústředním tématem knihy je ale především role Panny Marie v možných cestách Romů z periferií do centra dění. Právě analogie periferie a centra je autorkou často používaným zobrazením tématu a velmi názorně pomáhá porozumět kontextu. Marie v textu nabývá různorodých podob: na jedné straně je autorkou vylíčena jako globální a nadnárodní figura, která komentuje mezinárodní dění a vyjadřuje obavy moderního světa. Supluje nedostatky římskokatolické církve, když dokáže odpovídat na výzvy nových forem religiozity, potřebu živé víry a touhu po zázracích. Slovy autorky, nabízí duchovní odpověd' na konzumerismus, racionalismus a sekularismus (s. 28-29). Na druhé straně se s ní v dalších kapitolách potkáváme v romských domovech jako s hluboce intimní partnerkou v každodennostech jejich obyvatel. Je to Marie soupeřící s agresivní misií letničních hnutí i napomáhající při milostné magii dospívajících dívek.

Autorka skutečně nahlíží postavu Panny Marie $\mathrm{z}$ různých úhlů. Všímá si např́íklad propojenosti jejích zjevení a př́ístupu okolí k nim: zjevení, která se „nehodí" svou lokací a kulturním kontextem, jsou oficiálními katolickými strukturami umlčována, stejně jako ti, kteři sami stojí na okraji. Autorka ovšem tvrdí, že odpor vůči Mariím, které neodpovídají tradičnímu zobrazení, značí implicitní rasismus a etnocentrismus, a právě proto jsou etnicky a kulturně odlišné podoby Marie nutné a potřebné pro emancipaci minorit $\mathrm{v}$ rámci církve. $\mathrm{V}$ tomto kontextu je zajímavé, že právě na Slovensku je Panna Marie Sedmibolestná církví posvěcenou národní patronkou - to je unikátní pozice, která neplatí pro žádný jiný nezávislý národ (s. 44). Autorka se tedy trefně ptá: když Marie naplnila svou roli pro Slováky, dokáže totéž nabídnout i slovenské romské menšině? Ta tvoří asi $7 \%$ slovenské populace a vypořádává se $\mathrm{s}$ řadou etnických stereotypů (např́klad automatickým spojením Romů s životem v osadách). Volí ve většině př́ipadů cestu neviditelnosti, nezúčastněnosti a mlčení (s. 46).

Je důležité zdůraznit, že autorka si důkladně všímá toho, jak je náboženský život Romů pojmenováván a zobrazován. Základní otázkou vznášenou různými aktéry v tomto kontextu je, zda jsou Romové stejní křestané jako ne-Romové. Téma jejich ,,jinakosti“" je cirkulující konstantou (s. 49). 
Romská religiozita je pak vnímána v mnoha stereotypech: jako nestabilní, domácí, formálně deklarovaná, ale také exotická, adaptabilní, konzervativní a kamuflující. Zajímavým paradoxem tak je, že Romové se na jednu stranu nachází na periferii mainstreamového křestanství, na straně druhé jsou však každodenními zapálenými praktikujícími. Lze jedině vyzdvihnout, že ve spleti stereotypů si autorka volí vlastní přístup: navrhuje, aby Romové byli vnímáni stejným způsobem jako členové majoritní společnosti, kde se samozřejmostí rozeznáváme experimentální, mnohoúrovňovou a proměňující se religiozitu, stejně jako brikolážovou a afiliací nevymezenou víru (s. 54). Navrhuje tedy mluvit o ,tradičním romském křestanství“, jež funguje na základě ,produkce a reprodukce unikátního systému nepsaných pravidel a hodnot, které jsou zcela zakotvené $\mathrm{v}$ křestanské víře v Boha, Ježíše a Pannu Marii“ (s. 50). Postavení na okraji společnosti je zde přitom zcela zásadním aspektem. V této souvislosti je například skvělým postř̌ehem, že stále častější konverze k letničnímu hnutí lze vnímat jako hlas po tom být rozpoznán, a nahradit tak marginální pozici ve společnosti jinou identitou. Právě letniční hnutí je ale často většinou společnosti vnímané jako sekta a uspokojivé etablování v majoritní společnosti Romům neusnadňuje. Romové se tak ocitají v začarovaném kruhu: ani letniční hnutí, ani katolictví neaktivizuje jejich etnické sebevědomí (s. 67). Dokáže být katolická Marie odpovědí na náboženskou a etnickou marginalizaci? Může ochránit romské kulturní dědictví a tradiční romství? To je otázka, která otevírá další kapitoly.

Romská religiozita stojí na piliřích, jakými jsou tabu a rituály životního cyklu, zakotvení v prrítomnosti, eschatologie, náboženský dekorativismus, strach z mrtvých, kouzelnictví, magie lásky a ublížení, léčení a ochrana, předvídání budoucnosti, proklínání, př́ísahy, zázraky a pragmatické smlouvy s Bohem. V publikaci je mnoho výborně vybraných příkladů, které ilustrují povahu romské náboženské tradice. Namátkou zmíním např́iklad odmítání víry ve vzkřríšeného Krista, která je v konfliktu $\mathrm{s}$ vírou ve škodící duše oživlých mrtvých (s. 58). Atraktivitu publikace nepochybně zvyšují také fotografie z romských domácností dokumentující „,svaté koutky“, domácí oltáříky a náboženskou výzdobu, díky nimž je Marie stále přítomna v každodennosti svých hostitelů. Je pak snazší porozumět tomu, že Marie je chápána jako př́itomna in situ, otevřená dohodám všeho druhu a ochotná $\mathrm{k}$ běžné komunikaci. Marii zde potkáváme jako součást Svaté Trojice OtecMatka-Syn, jako odvážnou bojovnici s dáblem i obyčejnou ženu, která trpěla porodními bolestmi a má měsíční periodu. Jak ale autorka trefně poznamenává, může zde fungovat pouze taková Marie, která nenabourává tradiční romský systém; jen ta, která „má romské srdce“ (s. 117). Nebylo by vlastně vůbec na škodu, kdyby v celé publikaci bylo ještě více příkladů, př́iběhů i delších citací z rozhovorů. Právě taková nahlédnutí do tématu umožňují jeho plastičnost a mnohovrstevnatost zprostředkovat čtenářům.

V poslední kapitole autorka dochází k závěru, že pro slovenské Romy funguje religiozita jako klíčový sociální regulátor. Podnětným poznatkem je, že i přes svůj konzervatismus a tradicionalismus mají Romové blízko k ultra-moderním náboženským formám typu brikoláže (s. 125). Katolictví je potom platforma, na které Romové vyjednávají svou pozici s mainstreamovou společností. Katolictví tak plní funkci integrace i segregace (s. 127). Marie je především žena a ochránkyně, jež je srdcem romské náboženské tradice - právě proto je prvním cílem útoků letničních hnutí, která chtějí radikálně přepsat tradiční romský příběh, což ale následně narušuje celou komunitu (s. 142). Jednou z jiných cest k emancipaci, než je letniční hnutí, by podle autorky bylo obrácení k ojediněle se vyskytujícím formám označovaným jako Chocolate Mary, tedy Marii romské nejen srdcem, ale i vzezřením (s. 147).

Další prostor bych ráda věnovala několika slabinám knihy. První kapitola se mi jeví zbytečně obsáhlá a faktografická. Ačkoliv jde o úctyhodný přehled historie, symboliky a zjevení Panny Marie, čtenář/ka ve skutečnosti celý tento výčet pro další čtení nepotřebuje. Mnohem více bych uvítala a považovala bych to za vědecky poctivější 
řešení - kdyby alespoň část tohoto rozsahu byla věnována metodologii. Téměř úplnou absenci popisu sběru dat, výzkumné etiky a analýzy (až na drobné poznámky v textu) považuji za největší slabinu jinak vydařené knihy. Jako čtenářka a zároveň kvalitativní výzkumnice si kladu mnoho otázek. Jak byly všechny výzkumy, z nichž se kniha skládá, realizovány? Byly součástí různých projektů a grantů? Kdy probíhaly a jakým způsobem? Šlo jen o rozhovory, nebo i pozorování? Byly rozhovory nahrávány? Jak se dařilo autorce získat důvěru informantů (zvlášt s ohledem na fakt, že měla možnost v domácnostech fotografovat)? Kdo vlastně byli informanti - muži, ženy, rodiny, děti? Hovořila i s předáky komunit, sociálními pracovníky, faráři či pastory? Jak výzkumnice představovala informantům svůj výzkum? Jakým jazykem s nimi hovořila? Kolik času s nimi celkem strávila? Jaké měla dobré a špatné zkušenosti? Kde všude působila (jen v osadách, nebo např́íklad i v Bratislavě)? Měli informanti možnost konfrontovat výsledky výzkumu? Všechny tyto informace schází k celkové důvěryhodnosti výzkumu - tím spíše, že autorka hovoří o slovenských Romech jako o tiché minoritě (s. 46) a volí emickou perspektivu (s. 54). Její informanti ale jako reálné postavy z celkového obrazu určitým způsobem vypadávají. Také by mě zajímalo, jakým způsobem přistupovala autorka $\mathrm{k}$ analýze, zda pracovala pouze s textem, nebo zkoumala i svůj obrazový materiál a s jakými záměry. To vše považuji za významnou mezeru i proto, že je kniha evidentně směřována mezinárodní akademické obci, v níž se bez transparentně vymezené metodologie lze jen stěží pohybovat.

Vedle této zásadní poznámky mě napadá ještě několik drobnějších komentářů. Jednak se ptám, proč autorka na některých místech píše v autorském plurálu a jinde v první osobě jednotného čísla. Osobně by se mi také líbilo, kdyby text obsahoval více genderově orientovaných postřehů, které nelze v souvislosti s Pannou Marií pominout. Překvapilo mě také, že jsem nikde $\mathrm{v}$ textu nenarazila na legendu o ztracených kmenech Izraele, se kterou jsem se už v terénu sama několikrát setkala a která, zdá se mi, často funguje jako legitimizace svébytné romské identity skrze biblickou autoritu.

$\mathrm{Na}$ závěr bych ale ráda zopakovala, že celkově autorčin přístup kvituji. Celý text provází rozumějící, citlivý přístup, průběžné vysvětlování a teoretické rámování empirických dat. Autorka je v tématu zběhlá, historicky informovaná, má velmi dobré postřehy a čerpá z obrovského množství zdrojů. Vítám též, že je text psán v angličtině - je určitě výhoda, že kniha takto překročí československé hranice, což pořád není u monografií $\mathrm{v}$ našem prostředí zvykem. Také obsahem a př́istupem je to kniha mezinárodní úrovně, až na výše zmíněnou výtku. Oceňuji také, že Marie je zde vnímaná jako svébytná aktérka. Neřeší se „pravdivost“ zjevení, ale automaticky se s nimi zachází tak, jak jsou emicky vnímána. Celkově jde o publikaci nadprůměrnou a rozhodně hodnou doporučení.

\section{ANDREA BELÁŇOVÁ}

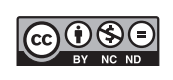

Religio: Revue pro religionistiku 29/2, 2021, 190-192.

https://doi.org/10.5817/Rel2021-2-6

This work can be used in accordance with the Creative Commons BY-NC-ND 4.0 International license terms and conditions (https://creativecommons.org/licenses/by-nc-nd/4.0/). 